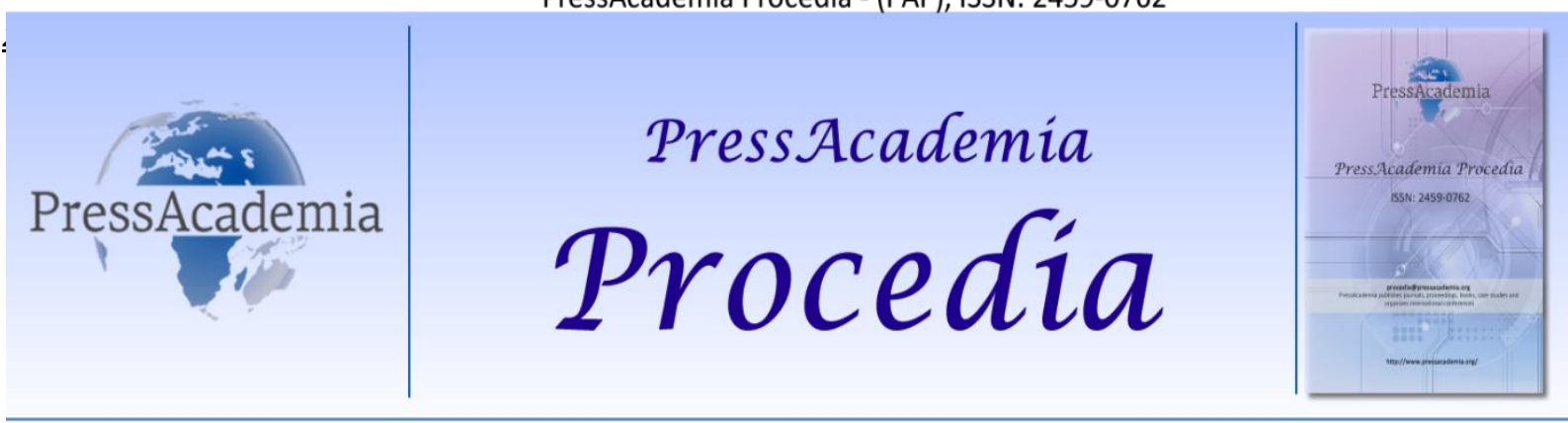

2nd World Conference on Technology, Innovation and Entrepreneurship

May 12-14, 2017, Istanbul, Turkey. Edited by Sefer Şener

\title{
BARTER SYSTEM AS AN INNOVATIVE AND ALTERNATIVE FINANCIAL AND TRADE MODEL DURING THE PERIODS OF ECONOMIC CRISIS AND RECESSION AND ITS IMPORTANCE FOR BUSINESSES
}

\author{
DOI: 10.17261/Pressacademia.2017.553 \\ PAP-WCTIE-V.4-2017(45)-p.340-348
}

Ozgul Uyan ${ }^{1}$

${ }^{1}$ Istanbul Gelişim University, ozguluyan@hotmail.com

\begin{abstract}
Today, increasing trade and financial integration between countries with globalization leads to intense competition and global economic crises in national and international markets. Due to these developments, the companies have some difficulties carrying on their business with traditional marketing and financing techniques and use alternative methods. One of them is barter system, which is based on the principle of buying and selling goods and services without using money. Barter is innovated form of exchange system, which has been used as a trading method since the early ages; today, it is also used as a counter-trade type. Barter offers companies various benefits such as moving overstock, utilizing idle capacity, increasing sales, finding new markets, supplying interest-free credit, conserving cash, debt configuration, foreign trade facilitation. The aim of this study is to examine the benefits of bartering in terms of commercial and financial dimensions. As a result of the study, it has been determined that barter is an innovative alternative to traditional mentality based on interest, and It is a type of trade and finance that will contribute to the country's economy by relaxing companies even in times of crisis. Nevertheless, it has been determined that barter instrument is not well recognized in Turkey, barter industry is not institutionalized, national and international barter transactions has not become widespread enough. Legal regulations are needed for effective, safe and widespread application of barter
\end{abstract}

Keywords: Barter finance, competition strategy, economic crisis, innovation management, international trade JEL Codes: M00; M10

\section{INTRODUCTION}

Today, it is often unsuccessful to be able to cope with the expansion of national and international trade volume and financial crises with standard financing and marketing techniques. The methods such as leasing, factoring and forfaiting are still money based and are ineffective at lowering the cost of money. For this reason, the best way to reduce the cost of money is not using money, which is the most important cost element of trade, to use non-money based techniques that can transform business resources economically. One of the methods that companies apply to increase the competitiveness both in the national and international markets and to overcome the cash troubles they have during crisis periods is barter method which is based on the principle of buying and selling goods and services without the use of money. Barter is an economy that has been practiced for centuries as the exchange of goods and services with other goods and services without using money (Terry and Gary, 1996: 167). Today, barter transactions are made in two types, bilateral (classical) and multilateral (modern) barter (Toroslu, 2010: 5); barter industry operates in three different ways, retail barter, corporate barter and international barter (Şimşek, 2004: 29); barter applications are performed in two types, full barter (\%100 barter) and partial barter (Söztutan, 2004: 30). Barter offers exceptional solution alternatives for increasing sales, moving overstock, utilizing idle capacity, appropriate financing, marketing and advertising, protection from crises, cash saving (Uyan, 2013a: 2). The purpose of this study is to introduce barter technique, to explaine operation process of barter in our country, to examine the benefits of barter for companies with commercial and financial aspects. In this context, firstly barter concept and its development are discussed. Then the barter types are explained with examples and the advantages 
and the difficulties of each type are explained. In the conclusion and suggestions section, the subject was evaluated according to the information provided and findings obtained, and suggestions for the future of barter system have been made.

\section{DEFINITION OF BARTER}

Conceptually, barter is a trading and financing tool that is based on centuries ago in the economy, though it is still new today. Simple definition of barter system is the exchange of goods or services without money (Edwards, 1996: 7). The Barter word is derived from the English language and is described as "Exchange (goods or services) for other goods or services without using money" in the Oxford Dictionary (Oxford Dictionaries, 2017). In Turkish, there is no barter word, but in many definitions of barter, the word "exchange" is used. In Turkish Language Dictionary prepared by Turkish Language Association (TDK), the exchange word is defined as "payment of the cost of deal made between two countries via reciprocal goods" (Güncel Türkçe Sözlük, 2017). In TDK's Dictionary of Economic Terms, the exchange word has been shown as the meaning of the English word "barter" (iktisat Terimleri Sözlüğü, 2017). Barter is a technique developed by inspiration from the exchange system which is the oldest and simplest form of trading methods (Karluk, 2003: 437). Barter as an international trade method means the exchange of goods between two countries without using money (Madura, 1992: 383). As a corporate trade type, barter is the name of a system in which companies exchange goods and services directly with other companies, especially in order to relieve liquid position and overstock (Yakovlev, 2000: 280). In foreign sources, barter is defined as the exchange of what you have for what you need (Tugend, 2009: 8). As a matter of fact, barter system in Turkey is also introduced with the concept of "give your excess and take your need" (Barter Yeni Ekonomi, 2002: 10). In emerging economies, the activities of barter traders do not only make it easier to spread existing resources more efficiently, but also provide for the growth of resources (Bauer, 2000: 4). Barter is therefore a special financial instrument that transforms the economic resources of countries and companies into economic gain. Today's modern barter system provides the exchange of goods and services in an organized market. In the literature, this organized barter type is referred to as "multilateral barter" and "financial exchange". But barter is a financing tool more contemporary and comprehensive than simple exchange (Özkan, 2002). Today, barter system is also referred to as "stock exchange of the goods and services" (Alptürk, 2009) and "free trade" (Şimşek, 2004: 28). Indeed, today's modern barter system is created by the organizer company, there is a common market where companies that are members of the system can shop with each other and the goods or services purchased in this market are paid by goods or services produced or traded, not by money (Yeşiloğlu and Yiğit, 1996: 16). Therefore barter is a financing instrument that a firm can buy goods and services needed and a trading technique by which a firm can sell goods and services produced.

\section{DEVELOPMENT OF BARTER}

On the basis of barter, there is the exchange of something you have for something you need. In the early ages when trade was made in the simplest form, mankind was using their excess for their needs, so that goods and services were exchanged between sides. First the coin, then banknote, started to be used in the economy, then exchange and similar contracts have fallen into desuetude. The exchange system, which lost its significance along with the invention of money, become a current issue of companies and countries again in order to get rid of the world economic crisis of 1929 (Uyan, 2013a: 1). Due to the collapse of trade, from 1930 to 1933, most European countries have made many barter agreements. In particular, Germany has supplied food and raw materials from European and Latin American countries through barter. In those years, due to the war and the economic crisis, international barter, one of the counter-trade techniques, was applied. But then barter applications began to spread to the business level as well (Sürmen and Kaya, 2001: 131). On the other hand, private sector companies have always used the corporate barter method by themselves, they have bought their needs from the company and they have sold their products to same company, so they made bilateral barter. Over time, barter technique was renewed, innovated and systematized with the effect of technological developments, organized barter applications operated by barter companies has started, thus barter started to be applied as multilateral changes between goods and services.

According to US Department of Commerce, barter constitutes about $30 \%$ of total world trade in various forms. The Business Trend Analysts research has found that $40 \%$ of world trade is done with barter system. Again according to US statistics, barter trade has increased around 16\% per annual (Sayglıoğlu, 2009: 197). The oldest known barter organization was established in Switzerland in 1934 (Arslan and Aykutlu, 1999: 2-3). Organized barter system is most commonly applied in USA. Today more than 900 barter companies are operating in various countries and more than 700 thousand companies actively trade barter (Toroslu, 2010: 68). In Turkey, barter organizations have been operating since the 1990s (Bayrav, 2009: 8), and barter system began to be recognized in 1994 economic crisis when overstock of companies were utilized by barter. 


\section{BARTER TYPES, ADVANTAGES AND DIFFICULTIES}

\subsection{Retail Barter (Organized Barter)}

Retail barter is a type of barter that a company that is a member of a barter organization pays for goods or services bought from this barter market by selling goods or services that they produce or trade on this market. This practice is also known as barter exchange, retail barter or organize barter. Retail barter can be applied by the companies from every scale and sector, especially retailers, service producing companies and self-employed people (Uyan, 2013a: 29). There is no specific regulation for barter system in our country, in law and in national accounting standards, but the existing regulations do not preclude the establishment of barter companies and barter transactions through these companies (Arzova, 2000: 24; Acar and Tekşen, 2007: 5). Organized barter system has applied since 1930s in the world and since 1990s in Turkey. Today, a wide variety of goods and services are exchanged in barter market in our country, such as real estate, written and visual advertising, construction materials, airline tickets, car rental, hotel accommodation, hospital services, ready made clothing, furniture and educational services. Barter company, like a brokerage house, organizes the realization of the exchange between the member companies with barter system. This allows member firms to finance their needs by selling their own goods or services. Companies must sign barter agreement with barter company for membership (Erkan, 2000: 2-4). Main records (supplies and demands) showing which goods and services can be sold or bought in the system are operated by barter company and presented to the member companies. All of the members are served by barter brokers. Barter transactions are followed by barter authorities of member companies. Transactions are made on $100 \%$ barter (full barter) or partial barter basis. Barter organization records multilateral barter transactions made by member firms with barter checks as debt or receivables to the current accounts of the companies. (Şimşek, 2004: 29). Member companies can get their needs from barter system within the purchase credit limits (Erkan, 2000: 2). The purchase limit occurs when the company sells or provides guarantee in barter system (Uyan, 2013a: 71). Barter member can get the product need without paying money from another barter member in the system, and it has to sell its goods or services to the other barter members within the determined time in return (Erkan, 2000: 2). The member company that can not make the payment with the goods or services within the determined period has to pay its debt to the barter company in cash. In barter transactions, barter company is in charge of the brokerage house and all responsibility (in terms of price, quality, delivery, after-sales service) belongs to buyer and seller. The membership of the company can be terminated at the end of the barter membership contract or at the request of the member, or if the barter company considers it necessary (Uyan, 2013a: 71). The member company pays barter company operating barter system for all these services, the annual membership fee and the purchase and sales commission determined by the contract (Türk Barter Üyelik Sözleşmesi, 2011: 5). Retail barter operations are performed multilaterally. Multilateral barter eliminates situations where bilateral barter transactions are not possible or unsatisfied, and offers many alternatives to supply and demand (Zügül, 1998: 104-125). In multilateral barter transaction, many member companies come together through the organization of a barter company, and they make shopping with each other. This multi-sided and multi-commodity trading chain, made in the form of cross exchanges in barter market, continues unlimited.

Figure 1: Multilateral Barter Transaction

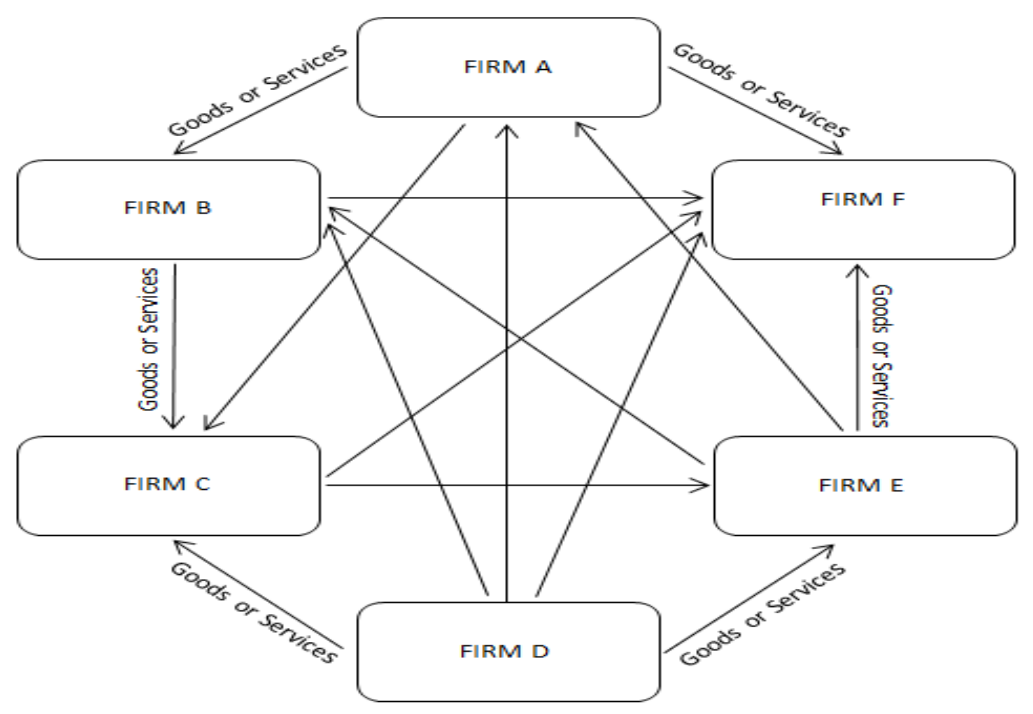


The main benefits of organized barter are as follows;

-Barter increases liquidity. If the companies buy the goods and services they need from the barter system, they will not face any payment difficulties and an increase in cash flow will be seen. The cash surplus in this case will enable the company to make new investments and grow (Polat, 2002: 63).

-Barter provides interest-free goods and service credit. Barter members pay the cost of goods and services they buy from the system with their own goods and services for a certain period of time (usually 12 months). However, if they can not sell their goods and services within this period, the debt is paid in cash at the end the period (Bayrav, 2009: 15). Thus, the companies that are members of barter system use goods and service credit with maturity up to 12 months at $0 \%$ interest rate.

-Barter allows overstock to be moved. Failure of the business marketing network to work effectively can result in excess stock. Especially the excess stock that can lose the update brings significant cost to companies. In this case, the companies can use barter system to move their overstock without affecting the existing sales and distribution network and receive the goods and services they need (Doğan, 2001: 44).

-Barter activates the idle capacity. Member companies can use their idle capacities in barter market by utilizing some of the capacity they can not fully use and thereby they can reduce both the unit cost of fixed costs and provide a part of the financing needed for production (Tekşen, 2006: 46-47).

-Barter provides a collection guarantee. Barter company guarantees the price of the goods sold with the guarantees it receives from the member companies. Thus, when the companies sell with the approval of barter company, the guarantor of the receivables of them becomes barter company, even if the buyers of the seller companies are bankrupt, receivables are collected by purchasing goods and services of other companies in the system (Polat, 2002: 63-64).

-Barter provides competitive advantage. Since the barter system is made by considering supply-demand balance, it is not allowed that many companies that produce the same product are presented in system. Thus the member company does not encounter many competitors operating in its own sector (Uyan, 2013a: 87).

-Barter offers free and effective advertising and promotion. Detailed information about the products of the member firms in barter system are recorded systematically in barter information bank, this information is available on the internet for use by all companies in the system (Gökmen, 2005).

-Barter increases sales. Since each supply in the barter system brings together the demand, the member companies can increase the production, the customer, the sales and the turnover (Polat, 2002: 60).

-Barter provides profit increase. Barter system increases sales through the use of idle capacity. Profit rates of member companies are increasing since sales increase without additional expense (Polat, 2002: 60) and the interest burden has ceased since cash is not used in the system (Doğan, 2001: 44).

-Barter enables effective marketing. Barter system categorizes the demands of the member companies, analyzes the market for the demands, brokers mediate the transactions of the members (Oduncuoğlu, 2007: 38-39). The system works like a private club, shopping is done only among the companies that are members of the system. Thus, member companies can make purchases and sales by meeting the companies they do not know (Tekşen, 2006: 48). The fact that the member companies do not try to find the suppliers of the products they want to buy and the customers to sell their products means that they can save on staff and time.

-Barter allows financial structuring. Barter system can be used to restructure companies' accumulated debt and risky receivables. For this, market debts are paid by utilizing the overstock and idle capacity of the company, and market receivables are collected as goods and services (Uyan, 2013b: 7).

-Barter system provides foreign trade convenience. As barter company deals with barter companies in other countries, system member companies get to know barter system members in other countries and get foreign trade with them (Polat, 2002: 64).

-Barter provides various macro advantages. The purchase and sale transactions among the member companies in barter system are made on an invoiced basis, this will contribute to prevent of informal economy (Toroslu, 2010: 56-57). 


\section{The main difficulties of organized barter are as follows;}

-The cash flow balance may be impaired. As long as the company that has sold goods and services in barter system can not find the goods and services demanded in the system, its receivable remains as an idle fund in barter system (Oduncuoğlu, 2007: 43-44).

-Debtor company can not make a sale in the system. If the company that is borrowed by buying goods in barter system, can not sell goods and services in the system for a certain period (usually 12 months), it will have to pay the system in cash (Polat, 2002: 66).

-Collection from the debtor company may not be possible. Receivables in barter system belongs to all the member companies. Barter company collects the receivables on behalf of the companies in the system. Barter company first tries to collect the receivable by converting guarantee that has received by debtor member into money. If the receivable can not be partially or fully collected, legal ways are tried. If it can not be collected again, barter company will show that receivable as expense (Demiral, 2000: 26).

- Commission and membership fee are incurred. Transaction commission and membership fee are paid to barter company for buying and selling transactions (Tekşen, 2006: 51). Although the member companies receive services such as brokerage services, free promotion, marketing, etc., the commissions and fees make a cost increasing effect for a company that can not use the system efficiently.

-There is a need to provide strong guarantees. Barter company guarantees payment to its member companies for receivables to be formed as a result of exchange of goods and services in the system. For this reason, barter company only permits companies that provide strong guarantees to use credit and purchase goods and services from the system. Companies that can not provide proper guarantee are asked to sell goods first. (Oduncuoğlu, 2007: 44).

-There is no special legislation of barter system in Turkey. However, since the components contained in the system are defined in separate trade laws, barter system can be operated (Oduncuoğlu, 2007: 44). These legal gaps can lead to the arbitrary establishment of barter companies and the difficulty of creditor companies.

-No special accounting standards have been established for barter system in Turkey. The system data is accounted for according to the uniform chart of accounts (Acar and Tekşen, 2007: 5). However, there is no explanation about how to implement the chart in barter transactions, so there are differences in the practice of registering barter transactions.

\subsection{Corporate Barter}

Especially in order to move their overstock, companies such as producers, main distributors and wholesalers exchanges their goods and services with the companies they are in business with, this is called corporate barter (Arslan and Aykutlu, 1999:9). The transactions can be made in partially cash, remaining barter or 100\% barter. (Şimşek, 2004: 30). Generally this type of barter is used by construction, automotive and advertising sectors. For example, contractors buy construction materials for floors. In automotive sector, sometimes the old car is exchanged. Media companies exchange their advertising services with the products of the companies they are advertising. Media organizations such as newspapers buy the products such as books, detergents and toys for advertisement, then they give them to the readers as promotions.

This type of barter means; when two companies are interested in each other's products, the company managers will see barter as a special type of transaction involving the goods exchange of business world. (Yakovlev, 2000: 280). As a matter of fact, corporate barter transactions are performed bilaterally. Bilateral barter is the simplest form of barter and is based on reciprocal exchange of the goods of two companies (Kırlığlu, Akaytay and Bağdat, 2005). In bilateral barter, there are only two parties that trade between each other, both parties are both buyer and seller.

Figure 2: Bilateral Barter Transaction

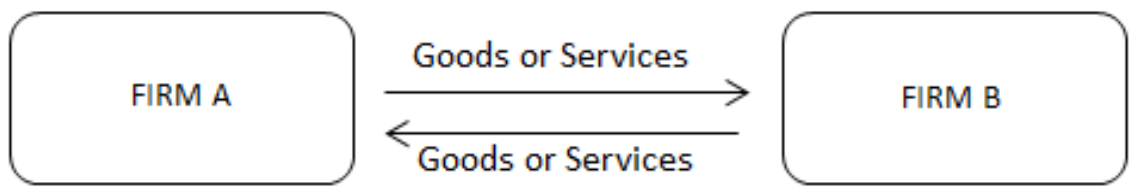

The main benefits of corporate barter are as follows (Şimşek, 2004: 30);

-Slow moving inventories are converted into current receivables. 
-Barter helps to evaluate the idle capacity.

-Barter allows to increase the market share with little or no cash investment.

-Barter enables the establishment of new marketing networks.

The main difficulties of corporate barter are as follows;

-Since the corporate barter is implemented as bilateral barter process, supply and demand can not be balanced. Because it may not be possible to fully match the value of the goods sold with the goods of the buyer, or the seller may not need the goods offered to him in response to what he wants to sell (Bayrav, 2009: 10).

-In order to implement corporate barter operations in a systematic way, it would be appropriate to set up a special barter department in company and to give instructions to the sales and purchasing personnel to do barter deals. Otherwise, employees prefer to sell and purchase by standard methods.

\subsection{International Barter (Counter-trade)}

International barter is generally implemented in the form of counter-trade aggrements (Uyan, 2013a: 31). Counter-trade is an international trade involving governments of two countries or companies in different countries (Toroslu, 2010: 20) and that is not all done in cash. Counter-trade is a general definition and is called in different ways depending on the goods sold, the type of payment made with the goods, the time of payment, the number of parties involved in the transaction, whether or not cash is used in the transactions (Durmuş, 2005: 13). Counter-trade refers to the exchange of goods, services, or technology whose prices are fixed in a certain currency, between countries for also the transfer of goods, services, technology or receivables, not for cash (Tekşen, 2006: 39). Counter-trade is preferred, especially when foreign currency distress is experienced and the value of the national currency is lowered or seen as an unsafe exchange instrument (Ersun and Arslan, 2010: 174).

Counter-trade has been recognized as an important mechanism in international trade and even developed countries have seen it as an alternative to little or no sales (Oyman, 2005: 40). Modern counter-trade practices in the world economy began with the 1929 world economic crisis (Uyan, 2013a: 31). Countertrade has had an important place in world trade, especially after 1945. It was developed under the leadership of the former eastern bloc countries. (Arzova, 2000: 7). Since the early 1970s, bilateral trade has been carried out between the countries developing and have liquid problems. Often mines, agricultural products and some industrial goods has been subject of counter-trade agreements (Arslan and Aykutlu, 1999: 10). The main types of counter-trade used in international trade, in other words, the forms of payment in foreign trade; buy-back, buy-sell, compensation, counter-purchase, offset deals, switch trading, clearing agreements and classical barter (Ersun and Arslan, 2010: 175). In practice, it is seen that the types of counter-trade traditionally consist of barter and clearing, and often carried out by state. Counter-trade techniques differ in terms of two main criteria. These are the duration of the relationship between the parties and the density and scope of the relationship. According to this; if the relationship between the reciprocal trading partners is strong, intensive, comprehensive and long-lasting, this will bring the parties closer to new possibilities for cooperation, closer to the rooted relations and and harmonizes the work and the arrangements between the parties. Otherwise, short-term techniques like barter take over (Ersun and Arslan, 2010: 177178).

Figure 3: Counter-Trade Types (Ersun and Arslan, 2010: 177)

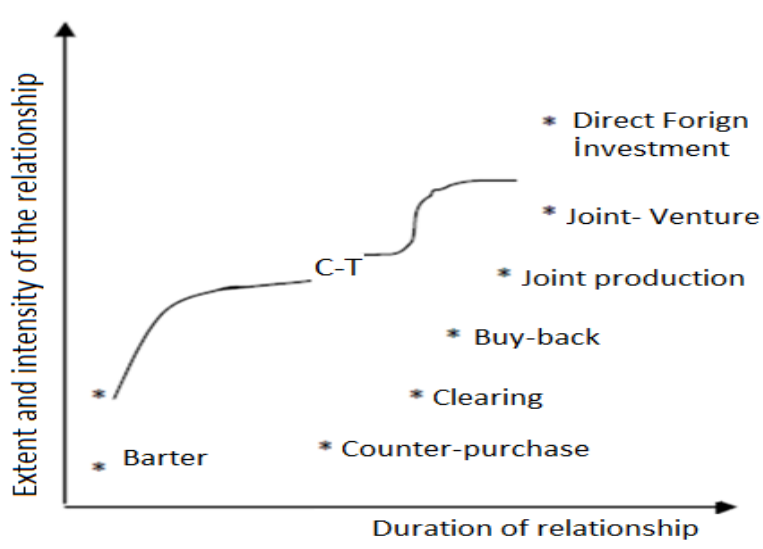


Barter, one of the types of counter-trade, is a trade conducted between two exporters and importers in two different countries by exchanging goods. The basic principle of the system is that the exporter has to import as much as the cost of the goods exported and the importer has to export the goods as much as the cost of the goods imported. In this type of trade, because of international exchange, the foreign trade transactions are realized without the use of convertible foreign exchange and foreign trade deficit does not arise. The goods exchanged by barter are generally unrelated with each other. The process time is relatively short and is about two years at the most. International barter deals are particularly made for strategic goods such as cereals, pulses, mineral ores (Ersun and Arslan, 2010: 175). Indeed, in the past, Iran has sold petroleum weapon; Pepsico, an American company in the 80 's, sold pepsi to Russia and bought Russian vodka Stolichnaya to market in US; Philips Morris bought urea for making artificial fertilizer by selling his own cigarette to Russia, then exported it to China and bought glassware to sale in US (Polat, 2002: 11).

The main benefits of international barter are as follows;

-Barter protects cash money in the country (Şimşek, 2004: 31).

-Barter increases the product variety for export (Şimşek, 2004: 31).

-Barter enables access to new markets (Şimşek, 2004: 31).

-Barter increases production capacities (Şimşek, 2004: 31).

-Barter provides continuity of prices of export goods (Şimşek, 2004: 31).

-When a country buys goods with barter it will also sell the goods, so barter will support to close foreign trade deficit (Ersun and Arslan, 2010: 175).

-In barter system, imports are realized without paying cash over USD and EURO, therefore there will be no decrease in Central Bank foreign exchange reserves due to barter trade (Toroslu, 2010: 56-57).

The main difficulties of international barter are as follows;

-Companies do not have enough information about procedures of barter technique.

- Logistics costs cause companies to hesitate to apply international barter.

\section{CONCLUSION}

Companies are turning to alternative economic methods in order to survive in today's economic conditions where financing is expensive, demand is decreased, market has become stagnant, competition has increased, global crises are experienced. One of these methods is barter model which can convert the resources economically and is not based on money. Barter, which has been used in different forms from the past to the present, has succeeded to be trade and finance method of every age. Today, innovative elements have been added to barter method which is the oldest method of trade and the method is being reused in this way. Today's barter industry is applied in three different types; retail (organized) barter, corporate barter and international barter. Barter is now a system that serves hundreds of sectors and hundreds of thousands of companies. Moreover, not only commercial enterprises, but also public institutions, professional organizations, municipalities and even governments are involved in the barter market to finance their needs with idle capacities. Companies in our country use barter system mostly for idle capacity, stock excess, liquidity problems, accumulated debts, risky receivables, financing and marketing problems.

While the use of barter is increasing worldwide, there are some difficulties in using and adopting the benefits of this technique in Turkey. In order to overcome these difficulties, some regulations especially for organized barter type are needed. First of all, legal arrangements should be made in Turkish legal system regarding the definition and operation of barter system, so that it will be possible to trust the system and to spread the system over a large mass. It is also important to regulate accounting standards for barter system in order to provide uniformity in accounting of barter transactions. It would also be useful for companies to come together and form a barter union for the institutionalization of barter industry, to provide education and training for the system, to set standards for the operation of the system, to adopt common codes of ethics, to create joint accounts. The system guarantee fund is used for the purpose of obtaining the product needed from outside the system or making cash payment to the member company in case the creditor member company can not purchase the product from the system and it is duty of the official authorities to operate this fund properly. It is necessary to apply the necessary sanctions to the member companies who do not supply of real price goods or services in barter market. On the other hand, with the special definition of barter transactions in the foreign trade legislation, international 
barter transactions will be increased, thus Turkey's foreign trade deficit will be reduced and the firms in our country will be recognized in foreign markets.

Barter technique presents important opportunities for the companies from every sector and every scale, even every country both in economic stagnation and welfare periods, and it is spreading as an alternative model today. Bartering will be one of the commercial and financial techniques accepted in economic life by making regulations that will ensure the healthy operation of the system in our country.

\section{REFERENCES}

Acar, D., Tekşen, Ö. 2007, "Barter Sisteminin Muhasebe Uygulamaları Açısından İncelenmesi”, Süleyman Demirel Üniversitesi i.i.B.F. Dergisi, vol. 12 , no. 3, pp. 1-18.

Alptürk, E. 2009, “Barter - Çoklu Takas Organizasyonu”, http://www.xing.com/net/bartergame/fikirler-oneriler-geribildirim297896/firmalarin-barter-sistemini-kullanma-nedenleri-ve-sekilleri-23062925/

Arslan, C. M., Aykutlu, F. 1999, “Barter Uygulaması”, Sirküler Rapor Serisi, TÜRMOB Yayınları-97, serial no. 27, Ankara.

Arzova, S. B. 2000, Barter İşlemleri-İşleyişi, Hukuki Yönü ve Muhasebeleştirilmesi, Türkmen Kitabevi, İstanbul.

Bauer, P. 2000, From Subsistence to Exchange and Other Essays, Princeton University Press, Princeton, N.J.

Barter Yeni Ekonomi. 2002, "Yeni Ekonomi, Barter: FazlanıVer, Eksiğini Al”, no. 49, pp. 10-11.

Bayrav, M. H. 2009, "Alternatif Ticaret ve Finansman Tekniği Olarak Barter Sistemi", Yayınlanmamış Yüksek LisansTezi, Marmara Üniversitesi, S.B.E., İstanbul.

Demiral, H. 2000, “Barter Şirketlerinde Tahsil Edilemeyen Alacakların Gider Yazılması”, Vergi Dünyası Dergisi, no. 228, pp. 67-69

Doğan, Z. 2001, "Yeni Bir Finansman Tekniği Olarak Barter ve Muhasebeleştirilmesi”, Muhasebe ve Denetime Bakış, no. 3, pp. 41-55

Durmuş, C. N. 2005, “Barter İşlemlerinin Muhasebeleştirilmesi ve Bir Öneri”, Yayınlanmamış Doktora Tezi, Marmara Üniversitesi, S.B.E., İstanbul.

Edwards, A. 1996, "Better Business Bartering”, Essence, vol. 27, no. 8.

Erkan, M. 2000, "Yeni Bir Finansman Aracı Olarak Barter'ın Diğer Finansman Teknikleri ile Karşılaştırılması", Active Bankacılık ve Finans Dergisi, no. 12 , pp. $80-85$

Ersun, N., Arslan, K. 2010, "İslam Ülkeleri Arasındaki Ticaretin Geliştirilmesinde Çok Taraflı Kliring Birliği Projesinin Rolü ve Önemi”, Muhasebe ve Finansman Dergisi, no. 48, pp. 172-190

Gökmen, S. 2005, "Barter Sistemi, Sisteminin İşleyisiyle Bu Sistemde Kullanılan Barter Çeklerinin 6183 Sayılı Kanun Karsısındaki Durumu”, Vergi Sorunları Dergisi, no. 201, pp. 66-71.

Güncel Türkçe Sözlük. (04.04.2017), Türk Dil Kurumu, http://www.tdk.gov.tr

iktisat Terimleri Sözlüğü. (04.04.2017), Türk Dil Kurumu,

http://tdk.gov.tr/index.php?option=com_bilimsanat\&view=bilimsanat\&kategori1=bakdetay2\&sozid=IKT

Kirlioğlu, H., Akaytay, A., Bağdat, A. 2005, "Bir Alternatif Finansman Modeli: Barter İşlemleri ve Muhasebeleştirilmesi”, Journal of Qafqaz University, no. 15 , pp. 15-31.

Karluk, R. 2003, Uluslararası Ekonomi-Teori ve Politika, 7.Baskı, Beta Yayınları, İstanbul.

Madura, J. 1992, International Financial Management, West Publishing, 3.Edition, St. Paul MN.

Oduncuoğlu, F. 2007, “Konaklama İşletmelerinde Barter Sistemi Uygulamasının Pazarlama Fonksiyonuna Etkisinin Analizi: Barter Sistemine Üye Olan Konaklama İşletmelerine Yönelik Bir Uygulama”, Yayınlanmamış Yüksek Lisans Tezi, Anadolu Üniversitesi, S.B.E., Eskişehir.

Oxford Dictionaries. (04.04.2017), Oxford University Press, https://en.oxforddictionaries.com/definition/barter

Oyman, M. 2005, "Pazarlama Bakış Açısıyla Karşılıklı Ticaret ve Uygulama Süreci", Pazarlama Dünyası, no. 2005-1.

Özkan, A. 2002, “Barter İşlemleri ve Muhasebe Uygulamaları”, Erciyes Üniversitesi Iktisadi ve Idari Bilimler Fakültesi Dergisi, no. 18, pp. 6386.

Polat, D. 2002, "Bir Finansman Tekniği Olarak Barter Sistemi, İşleyişi ve Türkiye`deki Barter Uygulamaları”, Yayınlanmamış Yüksek Lisans Tezi, Anadolu Üniversitesi, S.B.E., Eskişehir. 
Saygilioğlu, N. 2009, “Barter SistemininTanımı, Önemi, İşleyişi ve Etkileri”, Yaklaşım, no. 199, pp. 196-199.

Söztutan, S. 2004, "Türkiye'de Barter İşletmeleri ve Muhasebesi”, Yayınlanmamış Yüksek Lisans Tezi, Marmara Üniversitesi, S.B.E., İstanbul. Sürmen, Y., Kaya, U. 2001, “Barter ve Muhasebe İşlemleri”, Vergi Dünyası, no. 239, pp. 130-139.

Şimşek, M. S. 2004, "Parasız Ticaret: Barter", Kapital Medya Yayınları, i̇stanbul.

Tekşen, Ö.2006, "Barter İşlemlerinin Muhasebeleştirilmesi ve Vergilendirilmesinin Yeni Finansal Tekniklerle Karşılaştıılarak İncelenmesi: BirAraştırma, Doktora Tezi", iktisadi Araştırmalar Vakfı (Ünal Aysal Tez Değerlendirme Yarışma Dizisi; 5.), İstanbul.

Terry, N. L., Gary, E. K. 1996, Barter \&The Future Of Money: The Currency Crisis, Master Media Limited, Newyork.

Toroslu, M. V. 2010, Barter Işlemleri ve Muhasebesi, Adalet Yayınevi, Ankara.

Tugend, A. 2009, Trading What You Have for What You Need, New York Times.

Türk Barter Üyelik Sözleșmesi. 01.05.2011.

Uyan, Ö. 2013a, "Alternatif Bir Ticaret Modeli ve Finansman Tekniği Olarak Barter Sistemi ve Türkiye'deki Barter Uygulamaları", Yayınlanmamış Yüksek Lisans Tezi, İstanbul Aydın Üniversitesi, S.B.E., İstanbul.

Uyan, Ö. 2013b, "Finansal Sıkıntıdaki İşletmelerde Yeniden Yapılandırma Süreçleri”, Barter Finans Dergisi, no. 22, pp. 7-8.

Yakovlev, A. 2000, "Barter in the Russian Economy: Classifications and Implications (Evidence From Case Study Analyses)", Post-Communist Economies, vol. 12, no. 3, pp. 279-291.

Yeşiloğlu, T., Yiğit, S. 1996, "Barter ile Ticaret Çok Avantajlı Oldu”, Ekonomist, no. 47, s. 17.

Zügül, M. 1998, “Reform Ülkelerinin Dış Ticaretinde Barter ve Diğer Ödeme Şekilleri-Kırgızistan Uygulamaları”, Yayınlanmamış DoktoraTezi, Marmara Üniversitesi, S.B.E. 